\title{
Inter-annual and Decadal Variability of Sea Surface Temperature over Bay of Bengal
}

\author{
Md. Mizanur Rahman ${ }^{1}$, Nazlee Ferdousi ${ }^{1}$, Md. Abubakar Abdullah ${ }^{1}$, Yasuo \\ Sato $^{2}$,Shoji Kusunoki ${ }^{2}$ Akio Kitoh ${ }^{2}$ \\ SAARC Meteorological Research Centre, Dhaka, Bangladesh \\ Meteorological Research Institute, Tsukuba, Japan
}

\begin{abstract}
Sea surface temperature (SST) is one of the important oceanic parameters controlling the ocean climate. In view of this importance, an attempt was made in this study to examine the inter-annual and decadal variability of SST over the Bay of Bengal. The Bay is divided into three regions namely, i) South Bay, ii) Central Bay and iii) North Bay , during the period 1979-2006. The values of seasonal SST anomaly over these regions of Bay of Bengal are computed for the four meteorological seasons like, Winter (December-February), pre-monsoon (March-May), Monsoon (June-September) and post-monsoon (October-November). The variability of seasonal SST anomaly was examined using various statistical methods, on inter-annual and decadal time scale and the results are inter-compared. The SST anomaly over the above region of Bay of Bengal for all seasons showed an increasing trend except in the North Bay during the period 1979-2006, which showed almost neutral trend. The SST showed an increasing trend more particularly after 1992.
\end{abstract}

Key words: sea surface temperature, trend, variability, seasons, Bay of Bengal

\section{Introduction}

Bay of Bengal forms the northeastern part of the Indian Ocean, opened to the Ocean to the south only, and in other directions it is surrounded by land, much of it extremely mountainous. The land masses around the bay have a profound effect on the weather regimes of this area and knowledge of the relevant physical features of these land masses is essential to an understanding of the meteorological phenomena affecting the Bay of Bengal. On the other hand, Indian Ocean constitutes a part of the major ocean basins of the globe, besides the Pacific and the Atlantic Ocean. The occurrence of phenomenon like El Nino (anomalous warming of the eastern and central equatorial Pacific Ocean) has attracted world attention considerably since mid 1970s. The importance of changes in sea surface temperature (SST) over the equatorial Pacific Ocean in global climate variability is extensively documented in the form of relationship between the El Nino Southern Oscillation (ENSO) and global climate anomalies (Walker 1923, 1924, Rasmusson \& Carpenter 1982, 1983, Ropelwski \& Halpert 1987, 1989, 1996, Shukla 1987, Mooley \& Paolino 1989, Sikka 1980). Although usually not as extreme or extensive as in the Pacific Ocean, warmer oceanic temperatures and anomalous convection pattern do also occur in central Indian Ocean (Chandrashekhar \& kitoh 1998, Saji et al. 1999). The inter-annual variability in Indian Ocean is different too; little coherent behavior has been identified in it until now, in contrast to the Pacific and the Atlantic Oceans where several modes of variability have been evident (Anderson 1999). One possible explanation for the 
apparent lack of variability of Indian Ocean region is the different relative location of the major precipitation and through the release of latent heat, the associated atmospheric heating regimes. Meehl (1987) has discussed the annual cycle and inter-annual variability in tropical Indian Ocean and Pacific Ocean. He has suggested that inter-annual anomalies in the tropical Indian Ocean initiate over the Indian monsoon region during the northern summer and propagate southeastwards from northern summer to winter. Webster et al. (1999) had shown that in the second half of 1997 (the year of the most severe El Nino event of the $20^{\text {th }}$ century), anomalies in SST developed in Indian Ocean (cold in the east and warm in the west), a state known as Indian Ocean dipole, they relate the ocean temperature distribution to increasing rainfall over east Africa and reduced rainfall over Indonesia and to the associated shift in atmospheric heating patterns. Singh and Sarker (2003) have observed that

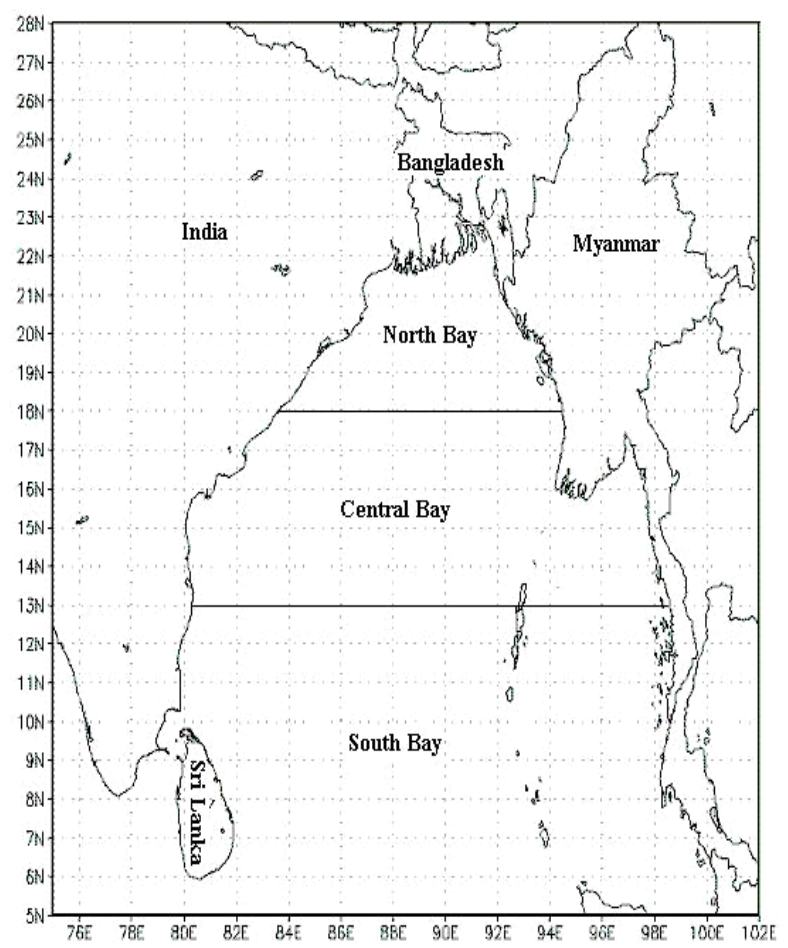

Fig. 1. Map showing the Bay of Bengal and its divided into three regions namely i) South Bay $\left.\left(5-13^{\circ} \mathrm{N}, 78-100^{\circ} \mathrm{E}\right) \mathrm{ii}\right)$ Central Bay $\left(13-18^{\circ} \mathrm{N}, 80-98^{\circ} \mathrm{E}\right)$ and iii) North Bay (18$\left.22^{\circ} \mathrm{N}, 84-94^{\circ} \mathrm{E}\right)$. during the period 1985-98, the SST in the coastal region of North Indian Ocean showed increasing trends in all the seasons and the SSTs in the Island regions during Winter season, showed decreasing trend. Singh (1999) has reported a significant increasing trend in the SST values over the Arabian Sea during May. Singh (1998) has also reported positive SST anomaly values over South Arabian Sea $\left(0-10^{\circ} \mathrm{N}\right)$ and negative SST anomaly values over North Arabian Sea $\left(10-25^{\circ} \mathrm{N}\right)$. Khan et al. (2000) have observed the increasing trends in SST and the frequency and intensity of tropical cyclones in the Bay of Bengal, especially during May and November, which account for the highest number of intense cyclones in the Bay of Bengal. Thus, the Bay is showing increasing importance and relevance in global climate variability in recent years particularly, after the 1997 El Nino event.

In view of this importance of Bay of Bengal an attempt has been made in this study to examine the interannual, inter-seasonal and decadal variability of SST over i) South Bay $\left(5-13^{\circ} \mathrm{N}, 78-100^{\circ} \mathrm{E}\right)$ ii) Central Bay $\left(13-18^{\circ} \mathrm{N}, 80-98^{\circ} \mathrm{E}\right)$ iii) North Bay $\left(18-22^{\circ} \mathrm{N}, 84-94^{\circ} \mathrm{E}\right)$ during the period 1979-2006.

\section{Methodology}

Monthly data of SST over Bay of Bengal were extracted from the high resolution Meteorological Research Institute (MRI) - Atmospheric General Circulation Model (AGCM) and then were converted into seasonal and decadal values. MRI-AGCM model has $20 \mathrm{~km}$ x 20 $\mathrm{km}$ latitude-longitude grid. Details are found in Mizuta et al. (2008). After extracting data from this model, the mean seasonal SST anomaly values were computed for the following four meteorological seasons viz, winter (Dec-Feb), pre-monsoon (Mar-May), SW Monsoon (September) and Post-monsoon (Oct-Nov) for each year during the study period of 1979-2006. The anomaly values were computed as departure from the respective mean values for the above period. These SST anomaly values were further averaged over the following three regions: i) South Bay ii) Central Bay and iii) North Bay are shown in (Fig.1). The variability of seasonal SST anomaly was examined using various statistical methods on inter-annual, seasonal as well as decadal time scale. The series of seasonal SST anomaly values, thus obtained were also subjected for existence of trend. The trend analysis was carried out based on the method of least squares. 


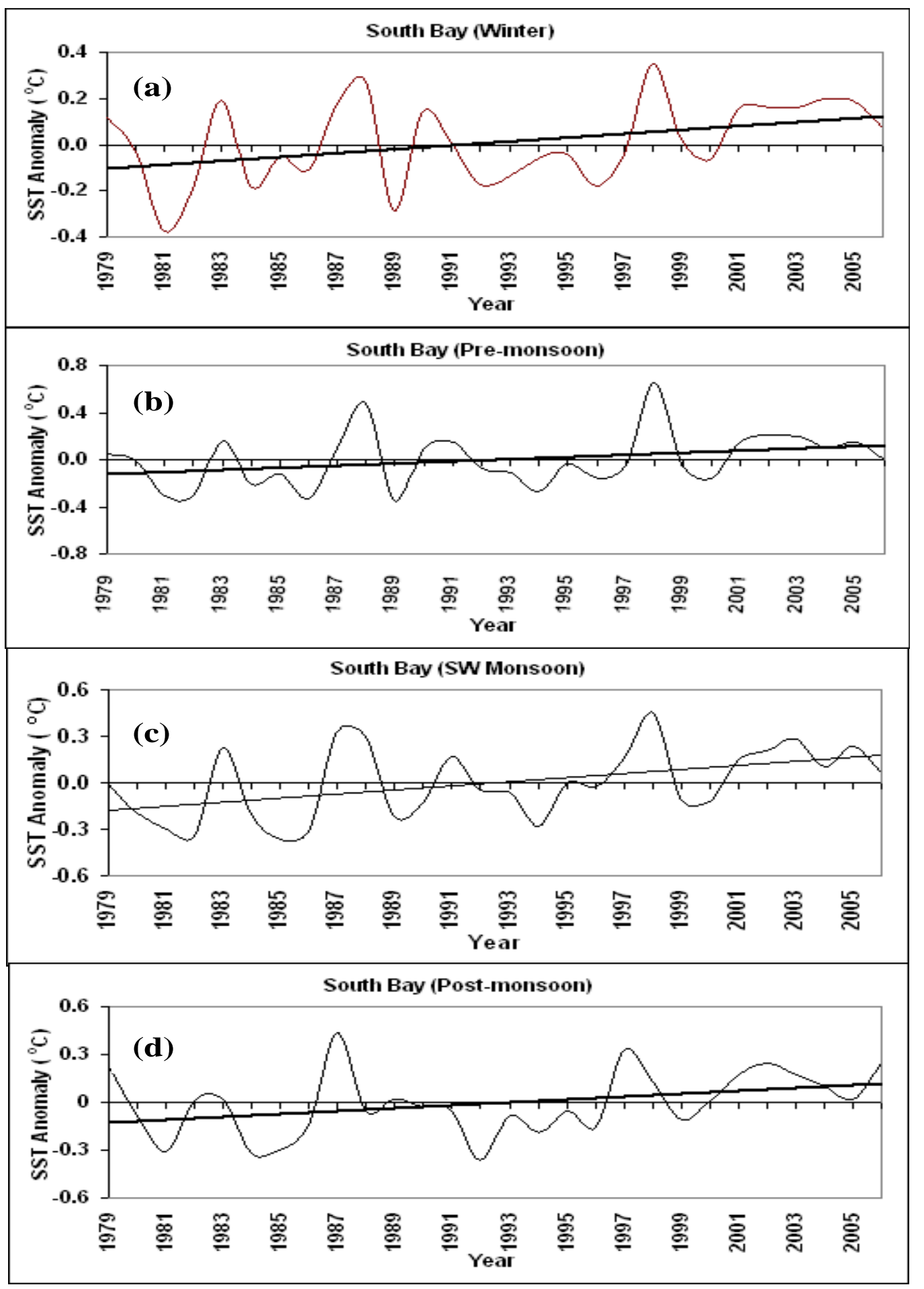

Fig. 2. Inter-annual variability of seasonal SST anomaly over South Bay: (a) Winter, (b) Pre-monsoon, (c) SW Monsoon, and (d) Post-monsoon seasons during the period 1979-2006 
Results and Discussion

\section{Variability of SST over South Bay of Bengal Inter-annual Variability of SST}

Fig. 2 depicts the inter-annual variability of SST anomaly over South Bay of Bengal for the four seasons viz, Winter (Dec-Feb), Pre-monsoon (Mar-May), SW Monsoon (Jun-Sep) and Post-monsoon (Oct-Nov) respectively, for the period 1979-2006. It is observed from this figure that the seasonal SST during all the four seasons is characterized by a high degree of interannual variability. It is also seen that the seasonal SST shows an increasing trend in its value during the above period, which is statistically significant at $5 \%$ level as shown in Table 1.

Table 1. Trends of SST over Bay of Bengal ( ${ }^{\circ} \mathrm{C} /$ decade) during the period 1979-2006.

\begin{tabular}{l|c|c|c|c|c}
\hline Region/Seasons & Winter & Pre-monsoon & SW Monsoon & Post-monsoon & Annual \\
\hline South Bay & 0.083 & 0.09 & 0.133 & 0.089 & 0.102 \\
Central Bay & 0.034 & 0.068 & 0.067 & 0.043 & 0.053 \\
North Bay & -0.03 & 0.004 & 0.003 & -0.007 & 0.01 \\
\hline
\end{tabular}

\section{Decadal Variability of SST}

Fig. 3 depicts that the decadal variability of SST anomaly over South Bay for the four seasons viz, Winter, Premonsoon, SW Monsoon and Post-monsoon respectively, for the period 1979-2006. It is observed that the seasonal SST anomaly for all the four seasons is negative during the decades 1979-1988 and 1989-1998

and positive in the decade 1999-2006. During SW Monsoon season, the SST anomaly for the decade 19891998 is zero, which indicates normal SST values. The decadal SST anomaly values depict a progressive rise for the coming decades with the last of the past decade (1999-2006), exhibiting the highest value of decadal SST anomaly among all other decades in this study.

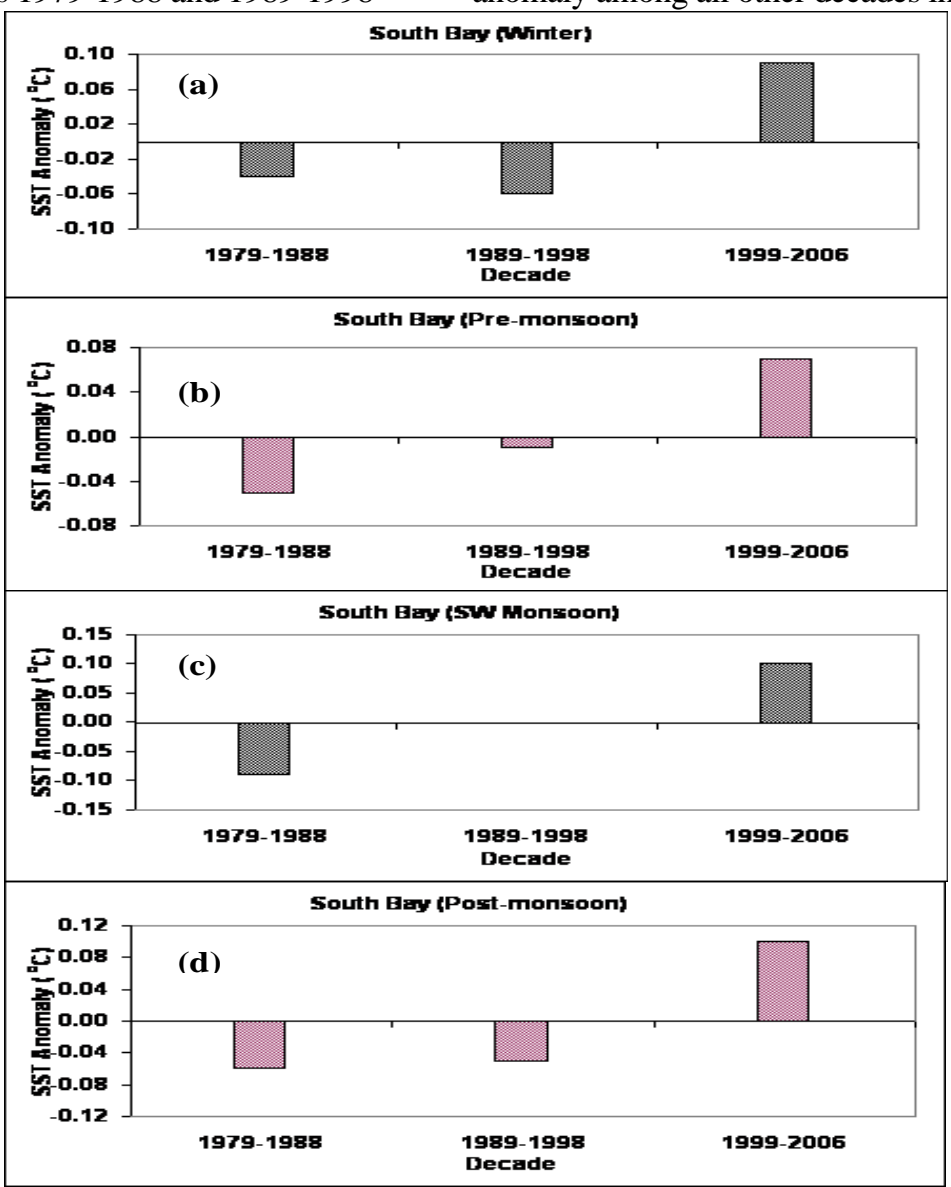

Fig. 3. Decadal variability of seasonal SST anomaly over South Bay for (a) Winter (b) Pre-monsoon (c) SW Monsoon, and (d) Post-monsoon seasons for the period 1979-2006. 
Md. Mizanur Rahman et al./Inter-annual and Decadal.......

\section{Variability of SST over Central Bay of Bengal Inter-annual Variability of SST}

Fig. 4. depicts the inter-annual variability of SST anomaly over Central Bay for the four seasons viz, i) Winter (Dec-Feb), ii) Pre-monsoon (Mar-May), iii) SW Monsoon (Jun-Sep) and iv) Post-monsoon (Oct-Nov) respectively, for the period 1979-2006. It is observed from this figures that the seasonal SST during all the four seasons is characterized by a high degree of interannual variability. It is also clear that, the seasonal SST showed an increasing trend in its value during the above period, which is statistically significant at 5 $\%$ level as shown in Table 1.
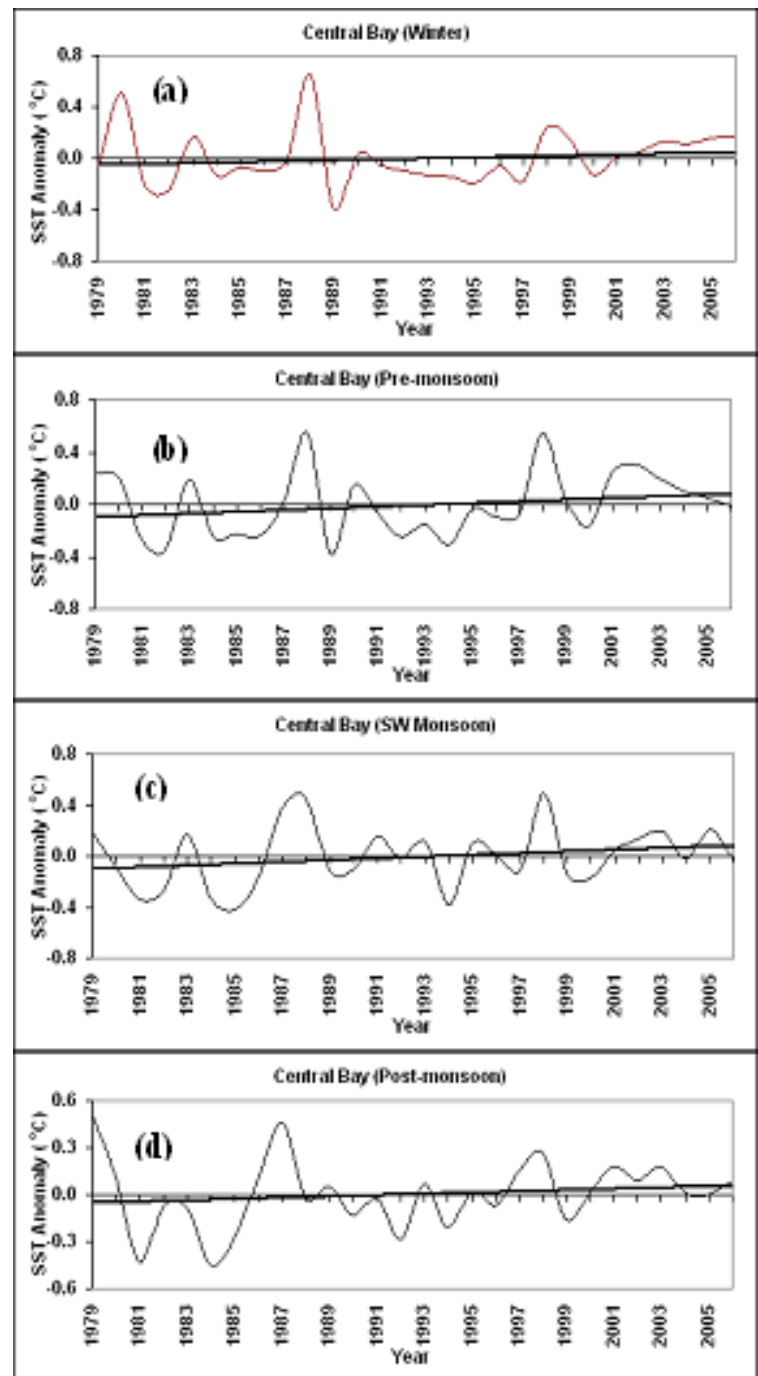

Fig. 4. Inter-annual variability of seasonal SST anomaly over Central Bay for (a) Winter (b) Pre-monsoon (c) SW Monsoon and (d) Post-monsoon season during the period 1979-2006
Fig. 5 depicts, the decadal variability of SST anomaly over Central Bay for the four seasons viz, Winter, Premonsoon, SW Monsoon and Post-monsoon respectively, for the period 1979-2006. It is observed that the seasonal SST anomaly for all the two seasons viz, Pre-monsoon and Post-monsoon is negative during the decade 1979-1988 and 1989-1998 and is positive for 1999-2006. For winter season, the seasonal SST anomaly is positive for the decade 1979-1988 and

\section{Decadal variability of SST}

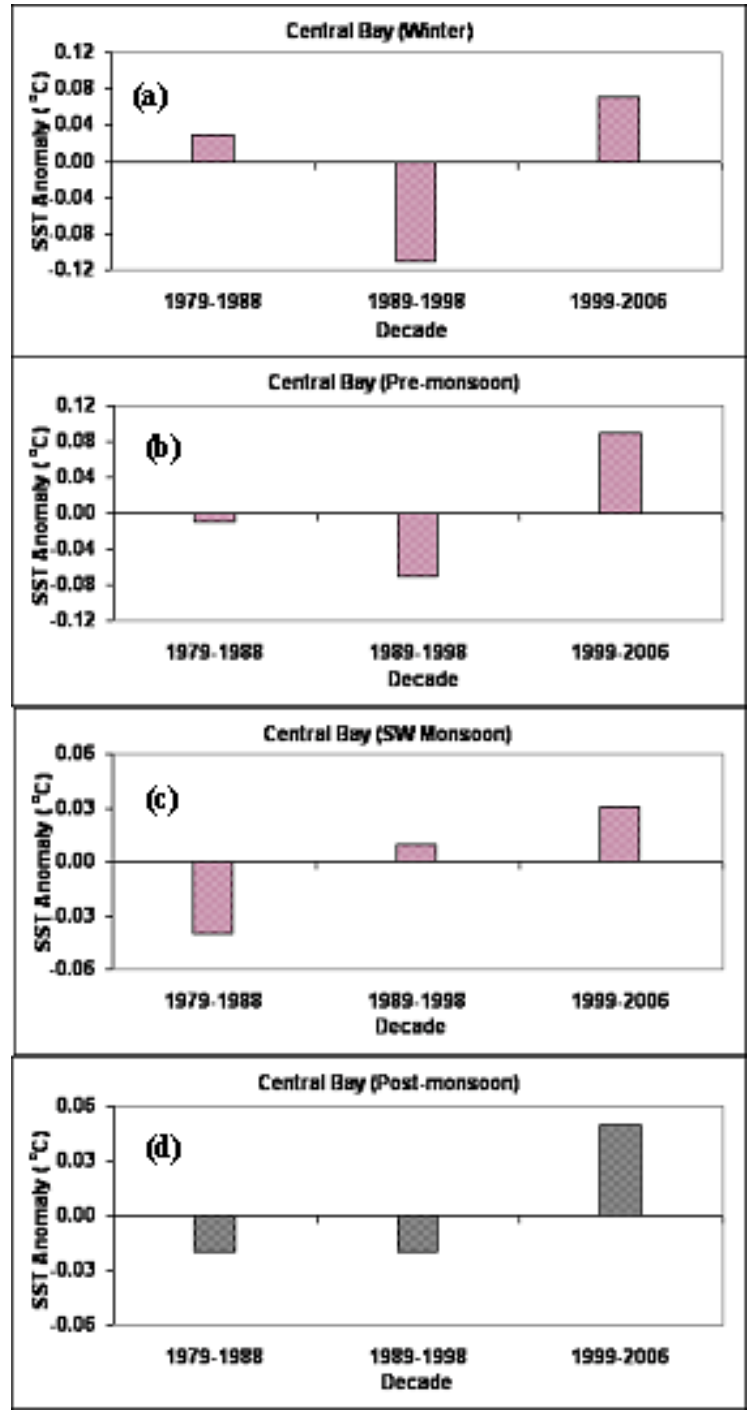

Fig. 5. Decadal variability of seasonal SST anomaly over Central Bay for (a) Winter (b) Pre-monsoon, (c) SW Monsoon, and (d) Post-monsoon seasons for the period 1979-2006. 
1999-2006, and is negative during 1989-1998. For SW Monsoon season, the SST anomaly is positive for the decade 1989-1998 and 1999-2006, and is negative during 1979-1988. The decadal SST anomaly values depict a progressive rise for the coming decades with the last of the past decade (1999-2006), exhibiting the highest value of decadal SST anomaly among all other decades in this study.

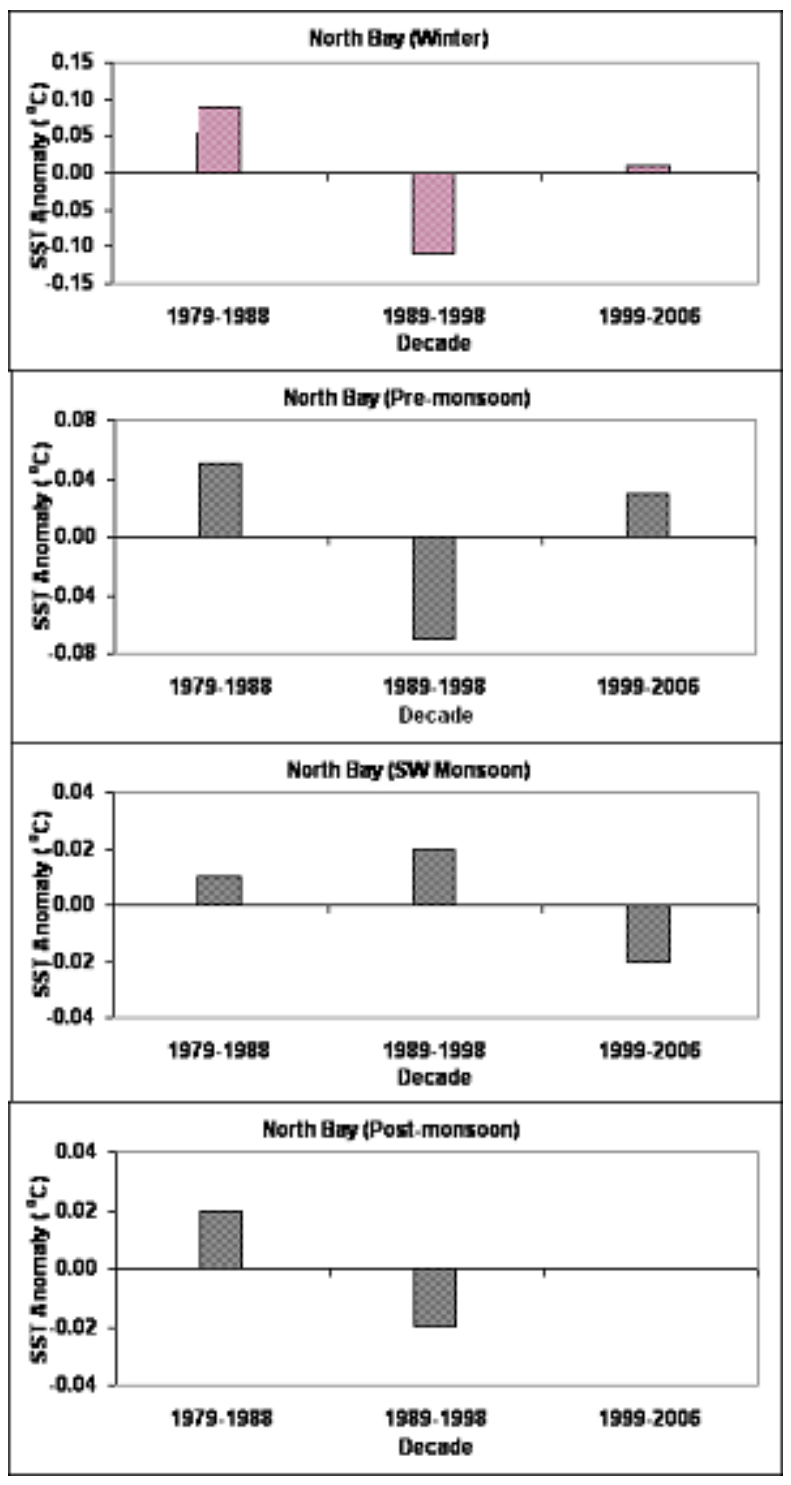

Fig.6. Decadal variability of seasonal SST anomaly over North Bay for (a) Winter, (b) Pre-monsoon, (c) SW Monsoon, and (d) Post-monsoon season during the period 1979-2006.

\section{Variability of SST over North Bay of Bengal Inter-annual Variability of SST}

The inter-annual variability of SST anomaly over North Bay for the four seasons viz, Winter (Dec-Feb), Premonsoon (Mar-May), SW Monsoon (Jun-Sep) and Post-monsoon (Oct-Nov) respectively, for the period 1979-2006 are studied. It is observed that (figures not shown here) the seasonal SST during all the four seasons is characterized almost neutral which is statistically insignificant (Table 1).

\section{Decadal Variability of SST}

Fig. 6 shows, the decadal variability of SST anomaly over North Bay for the four seasons viz, Winter, Premonsoon, SW Monsoon and Post-monsoon respectively, for the period 1979-2006. It is observed that the seasonal SST anomaly for all the four seasons is positive during the decade 1979-1988 and 1999-2006, and is negative for 1989-1998 except SW Monsoon for the last two decades. During SW Monsoon for the decade 1989-1998 SST anomaly is positive and is negative for 1999-2006. For Post-monsoon season, the SST anomaly for the decade 1999-1998 is zero, indicating normal SST values.

1. During the period 1979-2006, the inter-annual variability of seasonal SST anomaly values over South Bay and Central Bay for all the four seasons shows increasing trend with statistically significant.

2. The inter-annual variability of seasonal SST anomaly value over Bay showed increasing trend after 1992. The SST anomaly for the period 19791992 was negative indicating colder than normal SST and for the period 1993-2006 was positive indicating warmer than normal SST for the two regions of Bay of Bengal.

3. The decadal variability of seasonal SST anomaly value showed increasing trend over South Bay of Bengal for Winter, Pre-monsoon, SW Monsoon and Post-monsoon are 0.083, 0.09, 0.133 and 0.089 $\mathrm{C}^{\circ}$ per decade respectively. Similarly, the Central Bay of Bengal showed increasing trend over four seasons viz, Winter, Pre-monsoon, SW Monsoon and Post-monsoon at 0.034, 0.068, 0.067 and 0.043 $\mathrm{C}^{\circ}$ per decade respectively.

\section{Acknowledgements}

The first two authors are grateful to JICA Bangladesh for selecting them for attending a training course on 
Md. Mizanur Rahman et al./Inter-annual and Decadal........

'Capacity Development for Adaptation to Climate Change in Asia-Climate Change Analysis’ JFY 2008, (project number: 0884131). The first three authors are also grateful to the Meteorological Research Institute (MRI) for providing data of high resolution (20 km) AGCM for the study.

\section{References}

Anderson, D. 1999. Extremes in the Indian Ocean. Nature 401(6751):337-339.

Khan, T. M. A., O. P. Singh, and M. S. Rahman. 2000. Recent sea level and sea surface temperature trends along the Bangladesh coast in relation to the frequency of intense cyclones. Marine Geodesy 23:1-24.

Chandrashcker, A. and Kitoh, A.1998. Impact of localized sea surface temperature anomalies over the equatorial Indian ocean on the Indian summer monsoon. J. Met. Soc. Japan, 76(6): 841-853.

Mizuta, R., K. Oouchi, H. Yoshimura, A. Noda, K. Katayama, S. Yukimoto, M. Hosaka, S. Kusunoki, Kawai, and M. Nakagawa. 2008. 20 km-mesh global climate simulations using JMA-GSM model-Mean Climate States. J, Meteor, Soc, Japan 84:165-185.

Meehl, G, A. 1987. The annual cycle and interannual variability in the tropical Pacific and Indian Ocean regions. Mon. Wea. Rev. 115: 27-50.

Mooley, D. A. and D. A. Paolin. 1989. The response of the Indian monsoon associated with the change in sea surface temperature over the eastern equatorial Pacific. Mausam 40(4):369-380.

Rasmusson, E. M. and T. H. Carpenter. 1982. Variations in tropical SST and surface wind fields associated with the southern oscillation-El Nino. Mon. Wea. Rev. 110:354-384.
Rasmusson, E. M., and T. H. Carpenter. 1983. The relationships between eastern equatorial Pacific Sea surface temperature and rainfall over India and Sri Lanka. Mon. Wea. Rev. 111: 517-528.

Ropelwski, C. F. and M. S. Halpert. 1987. Global and regional scale precipitation patterns associated with El-Nino/Southern oscillation. Mon. Wea. Rev. 115:1606-1626.

Ropelwski, C. F. and M. S. Halpert. 1989. Precipitation patterns associated with the high index phase of southern oscillation. J. Climate 2:268-284.

Ropelwski, C. F. and M. S. Halpert. 1996, Quantifying southern oscillation precipitation relationships. $J$. Climate 9: 1043-1059.

Saji, N. H., B. N. Goswami, P. N. Vinayachandran and T. Yamagara. 1999. A dipole mode in the tropical Indian Ocean. Nature 401(6751):360-363.

Shukla, J. 1987. Long range forecasting of monsoons, In: Monsoons (Eds. J. S. Fein and P. L. Stephens). John Willey, New York. pp. 523-548.

Sikka, D. R. 1980. Some aspects of large scale fluctuations of summer monsoon rainfall over India in relation to fluctuations in planetary and regional scale circulation parameters. Indian Acad. Sci. (Earth Planetary Sci.) 89:179-185.

Singh, O. P. 1999. Multiple variability of summer sea surface temperature and evaporation over the Indian Seas. Mausam 50(4): 335-342.

Singh, O. P. 1998. Sea surface temperature and sea level pressure anomalies over the Arabian Sea during ENSO years. Mausam 49(2):264-266.

Walker, G. T. 1923. Correlation in seasonal variation of weather, VIII-A preliminary study of world weather. Memories India Meteorological Department 24(Part IV):75-131.

Walker, G. T. 1924. Correlation in seasonal variation of weather, IX-A further study of world weather. Memories India Meteorological Department. 24 (Part IX): 275-332. 
Nepal Journal of Science and Technology 12 (2011) 296-303 